\title{
Introduction: Re-reading Latin American Fiction
}

\author{
Rodica Grigore ${ }^{1}$
}

[Article copies available for a fee from The Transformative Studies Institute. E-mail address: journal@transformativestudies.org Website: http://www.transformativestudies.org (C2019 by The Transformative Studies Institute. All rights reserved.]

When John Asimakopoulos, editor-in-chief of Theory in Action, wrote to me some time ago asking if I would consider guest-editing an exclusive literary edition of the journal, I was surprised, enthusiastic and a bit apprehensive. I was enthused and surprised that the editors placed that level of confidence in me, and apprehensive about the size of the project and my ability to manage it.

My relationship with Theory in Action has a long history that I would like to mention briefly. I met Ali Shehzad Zaidi, the editor of the journal, through email correspondence more than ten years ago. I read and then translated into Romanian some of his exquisite essays on Mircea Eliade's work that were subsequently published by several Romanian literary journals. After discussing some technical matters related to translation of his text we proceeded to various literary topics. Then he invited me to submit essays to Theory in Action. I decided to submit two essays: one on Japanese novel (Silence by Shusaku Endo) and the other on Fernando Pessoa's Book of Disquiet. I have been always drawn to contemporary Japanese and Portuguese literature. While composing this introduction is dawned on me that this is the tenth anniversary of the publication of my essay on Silence.

After receiving the message from John that I mention above, I considered the possible topics for that literary edition issue of the journal he had suggested. I thought that Latin American fiction would be suitable from a variety of perspectives: first because Latin American literature is highly representative of contemporary culture and canonical from at least the second half of the $20^{\text {th }}$ century. I have always been intrigued by Latin American writers such as Jorge Luis Borges, Gabriel García Márquez, Juan Rulfo, and Alejo Carpentier, whose works played a key role in my

\footnotetext{
${ }^{1}$ Rodica Grigore, Ph.D., is guest editor of this special issue of Theory in Action. Address correspondence to: Rodica Grigore; e-mail: rodica.grigore@gmail.com.
} 